\begin{tabular}{|l|c|c|c|c|}
\hline ubmission & Review Process & Revised & Accepted & Published \\
\hline $22-06-2020$ & $12-07$ s/d 17-08-2020 & $18-08-2020$ & $27-08-2020$ & $28-08-2020$ \\
\hline
\end{tabular}

\author{
Published by: Politik Islam UIN Raden Fatah Palembang
}

\title{
Konflik Komunal Antar Warga NU dalam Pemilihan Kepala Desa Jermun Kecamatan Pampangan tahun 2016
}

\author{
Suhadi \\ Fakultas Adab dan Humaniora Universitas Islam Negeri Raden Fatah Palembang \\ Email: suhadiarwanda517@gmail.com
}

\begin{abstract}
This study discusses how the communal conflicts that occurred in Jermun Village in the election of the village head in 2016, conflicting communities in supporting Nahdlatul Ulama cadres who are contesting power to become village heads in Jermun Village.

The method in this research uses literature study and case studies to answer the problem formulation. Data collection techniques were carried out by searching for books that were relevant to this study and by interviewing three pairs of candidates who participated in political contestations with the people of Jermun Village.

The results showed that. 1. The conflict in Jermun Village was caused by differences in community choices. 2. Supporters vilify each other from other pedunkungs. 3. The community wants the candidate who is supported to win in the village head election. Because this is the occurrence of conflict between communities who participated in the election of the village head by voicing their voting rights.
\end{abstract}

Keywords: communal conflicts, village head elections, conflicts of interest

\begin{abstract}
ABSTRAK
Penelitian ini membahas bagaimana konflik komunal yang terjadi di Desa jermun dalam pemeilihan kepala desa pada tahun 2016, masyarakat yang berkonflik dalam mendukung


kader Nahdlatul Ulama yang berkontestasi merebutkan kekuasan untuk menjadi kepala desa di Desa Jermun.

Metode dalam penelitian ini menggunakan studi pustaka dan studi kasus untuk menjawab rumusan masalah. Tehnik pengumpulan data dengan dilakukan dengan cara mencari buku yang relevan denga penelitian ini dan dengan wawancara tiga pasang calon yang ikut kontestasi politik, engan masyarakat-masayarakat Desa Jermun.

Hasil penelitian menunjukan bahwa. 1. Terjadinya konflik di Desa Jermun di sebabkan bedanya pilihan masyarakat. 2. Pendukung saling menjelek-jelekan atar pedunkung lain. 3. Masyarakat ingin calon yang di dukung menang dalam pemilihan kepala desa. Karena ini lah terjadinya konflik antar masyarakat yang ikut serta dalam pemilihan kepala desa dengan menyuarakan hak suaranya.

Keywords: konflik komunal, pilkades, konflik kepentingan

\section{PENDAHULUAN}

Sebagian besar dari warga Jermun mayoritas beragama Islam dan merupakan Komunitas Nahdlatul Ulama . Meskipun tidak ada identitas yang resmi mengakui dan diakui sebagai Nahdlatul Ulama, tapi hal itu terlihat pada ikatan semangat keluargaan yang kuat. Mereka kokoh memegang prinsip terutama demi mempertahankan ajaran Ahlus Sunnah Wal Jamaah. Warga Nahdlatul Ulama di Jermun Keacamatan Pampangan kini bukan hanya yang hidup di desa seperti petani, penderes, dan seterusnya yang kurang memiliki daya tawar politik (political bargaining). Tak sedikit tokoh atau elit Nahdlatul Ulama yang menduduki jabatan strategis dalam lingkup pemerintahan daerah. (Abdurrahman, 2009)

Nahdlatul Ulama sebagaimasyarakat jamiyah lahir dari wawasan keagamaan yang bertujuan memajukan faham Islam ahli sunnah wal jama'ah aliran pemikiran Islam dibidang sosial kemasyarakatan berlandasan pada prinsip-prinsip keagamaan yang bercorak tasamuh (toleran) dan bersifat tawasud (moderat) Prinsip-prinsip sosial kemasyarakatan ini memberikan ruang gerak lebih luas kepada Nahdlatul Ulama' untuk merespons berbagai perubahan di lingkungannya, dan sangat toleran terhadap berbagai perbedaan yang berkembang dalam masyarakat plural seperti di Indonesia, tanpa terjebak dalam ekstrim kiri dan kanan yang secara fundamen sering kali merusak dimensi-dimensi solidaritas sosial dan kemanusiaan di Indonesia. Responsif, akurat, dan objektif atas kompleksitas problema empirik masyarakat bangsa tidak cukup hanya dengan mengandalkan peran Kyai (ulama') semata, sudah barang tentu membutuhkan tenagatenaga profesional muda yang trampil, visibel dan kapabel dalam memberikan solusi alternatif yang konseptual dan sistematis. Disinilah pendirian sebuah organisasi yang independen dan otonom Nahdlatul Ulama mengemukakan pikiran urgensinya. (Shadiq, 2004) 
Dalam pemilihan kepala desa Jermun dilaksanakan pada tahun 2016 persaingan warga Nahdlatul Ulama semakin terasa karena didasari pasangan yang bersaing adalah semuanya dari warga Nahdlatul Ulama yang mempunyai organisasi yang sama. Yang menjadi pertanyaan? Mengapa ketika dalam pemilihan kepala desa yang dilakasanakan pada tahun 2016 mereka bersaing dalam merebutkan kekuasaan. Bahkan kita mengetahui selayaknya orang yang berasal di organisasi yang sama harus saling mendukung dalam mendapatkan kekuasaan tersebut, ketika dalam pemilihan ini terjadilah konflik antar masyarakat yang mendungkung calon masing-masing terpecahnya suara warga Nahdlatul Ulama dalam menginginkan kekuasaan.

Bila mencermati kehidupan Nahdlatul Ulama, ternyata ada segenap upaya yang dilakukan untuk tetap bertahan ditengah modernisasi tata institusi kenegaraan termasuk dalam berdemokrasi. Nama besar Nahdlatul Ulama selain sebagai organsiasi, ternyata memiliki wajah kultural yang ternyata justru dari situlah sumber dari produk pemikiran politik Nahdlatul Ulama dalam setiap gejala politik yang nampak di permukaan. Seperti tentang corak masyarakat Nahdatul Ulama di Desa Jermun dalam domain kekuasaan,Terlebih kondisi masyarakat Nahdliyin di Jermun yang cukup dominan memegang tradisi ke- Nahdlatul Ulamaannya. Oleh karena itu, dalam kehidupan kebudayaan dan kehidupan sosial Masyarakat Nahdlatul Ulama, mau tidak mau tetap berpengaruh dan menyentuh ke dalam arena politik. Akibatnya, nilai-nilai kultural dari paraelite/penguasa dari kalangan Nahdliyin (Kiai, Ulama, maupun Tokoh Politik Nahdlatul Ulama ) yang dibentuk dan dipengaruhi oleh struktur sosial, agama dan kultur dengan sendirinya akan terbentuk skema pemikiran politik yang berbasis pada budaya Islam Nahdlatul Ulama. Seperti halnya yang digagas oleh Clifford Geertz tentang politik kultural, masalah skisme keagamaan menyebabkan skisme politik yang dikembangkan antara santri dan abangan di Indonesia. (Geertz, 1959)

\section{TINJAUAN LITERATUR}

Kajian mengenai konflik waraga Nahdlatul Ulama dalam pemilihan kepala desa dalam persaingan merebutkan kekusan, yaiatu menjadi kepala desa dalam kontestasi politik di pedesaan yaang menyebabkan ada jarak anatara pendukung satu dengan dua pasangan calon lainya.

Dalam skripsi menyingkap kuasa budaya, Mengakarnya Dominasi Nahdlatul Ulama dalam Demokratisasi di Banyumas. Bangun Udi Mustika,Bila mencermati kehidupan Nahdlatul Ulama, ternyata ada segenap upaya yang dilakukan olehnya untuk tetap bertahan ditengah modernisasi tata institusi kenegaraan termasuk dalam berdemokrasi. Nama besar Nahdlatul Ulama selain sebagai organsiasi, ternyata memiliki wajah kultural yang ternyata justru dari situlah sumber dari produk pemikiran politik Nahdlatul Ulama dalam setiap gejala politik yang nampak di permukaan. Seperti tentang corak masyarakat Nahdliyin Banyumas dalam domain kekuasaan, sesungguhnya hubungan antara Islam dan Jawa-isme yang berkembang di Banyumas telah melampaui 
wilayah konfrontasi keagamaan dan memasuki wilayah politik kekuasaan. Terlebih kondisi masyarakat Nahdliyin di Banyumas yang cukup dominan memegang tradisi keNahdlatul Ulamannya.

Oleh karena itu, dalam kehidupan kebudayaan dan kehidupan sosial Masyarakat Nahdlatul Ulama, mau tidak mau tetap berpengaruh dan menyentuh ke dalam arena politik. Akibatnya, nilai-nilai kultural dari para elite/penguasa dari kalangan Nahdliyin (Kiai, Ulama, maupun Tokoh Politik Nahdlatul Ulama ) yang dibentuk dan dipengaruhi oleh struktur sosial, agama dan kultur dengan sendirinya akan terbentuk skema pemikiran politik yang berbasis pada budaya Islam Nahdlatul Ulama. Dari akulturasi nilai Islam dan Jawa-isme di Banyumas yang memasuki wilayah politik inilah, maka politik kultural diidentikan sebagai bentuk siyasah bagi Nahdliyin dalam arena kekuasaan. Dalam ranah lokal, politik kultural Nahdlatul Ulama menempatkan kehidupan sosial sebagai sebuah medan pertarungan setiap individu Nahdliyin dengan anggota atau kelompok sosial lainya. Hal serupa berlaku dalam meningkatkan dan mempertahankan posisi sosial dan pengaruh kekuasaan di Banyumas. Politik kultural memberikan dorongan bagi setiap aktor Nahdliyin dalam memainkan peranya secara penting dengan cara menumbuhkan sikap berdemokrasi yang berpijak pada kesadaran akan eksistensi budaya dan adat istiadat setempat.

Studi ini memberikan focus perhatian politik Nahdlatul Ulama sebagai politik kultural. Bagaimana Nahdlatul Ulama menjadi poros penting dalam pilkada di Banyumas terbukti bahwa kemenangan pasti dari kader Nahdlatul Ulama, oleh sebab itu studi ini tidak menganalisis bagaimana proses terjadinya konflik komunal yang terjadi pasca pemilihan kepala desa.

Pelaksanaan Pemilihan Kepala Desa Serentak Di Kecamatan Petarukan Kabupaten Pemalang Tahun 2012 Dan Dampak Yang Ditimbulkan”, oleh Feri Budiarso dalam skripsinya bertujuan Hasil penelitian dapat disimpulkan bahwa 1) Pelaksanaan Pilkades serentak di Kecamatan Petarukan Kabupaten Pemalang meliputi sosialisasi perda, pembentukan panitia, pendaftaran calon, penjaringan dan penyaringan calon, pengundian tanda gambar, pelaksanaan kampanye, pemungutan suara, pengitungan suara dan penetapan calon terpilih; 2) Dampak sosial pelaksanaan pemilihan Kepala Desa serentak di Kecamatan Petarukan Kabupaten Pemalang meliputikewenangan panitia pilkades, lembaga yang berwenang mengatasi sengketa pilakdes dan faktor keamanan. Upaya yang dilakukan pemerintah Kabupaten Pemalang dalam mengatasi dampak pelaksanaan pemilihan Kepala Desa serentak di Kecamatan Petarukan Kabupaten Pemalang meliputi upaya penegakan aturan dan upaya sosialisasi dengan meningkatkan partispasi masyarakat di tingkat Desa.

Studi ini memberi focus perhatian kepada Pelaksanaan Pemilihan Kepala Desa Serentak Di Kecamatan Petarukan Kabupaten Pemalang Tahun 2012 Dan Dampak Yang Ditimbulkan oleh sebab itu studi ini tidak menganalisis bagaimana proses terjadinya konflik komunal pasca pemilihan kepala desa. 
Konflik Politik Dalam Proses Pemilihan Kepala Desa Tahun 2007 Di Desa Tarempa Barat Kecamatan Siantan Kabupaten Kepulauan Anambas", oleh Chevy Fantastic dari hasil penelitian tentang konflik politik dalam pemilihan Kepala Desa tahun 2007 di Desa tarempa Barat Kecamatan Siantan Kabupaten Kepulauan Anambas ada beberapa bentuk konflik politik yang terjadi. Hal ini dikarenakan oleh adanya pemaksaan, ancaman dan kekerasaan Fisik serta adanya money politik, fanatisme yang berlebihan dari pendukung calon kades, jugaadanya kepentingan politik yang begitu menggebu dari kandidat calon Kepala Desa yang ingin berkuasa sehingga menghilangkan nilai-nilai substansi untuk apa sebenarnya menjadi Kepala Desa, yang mana tujuan sebenarnya adalah membangun Desa. Penelitian ini menggunakan metode pengambilan data berupa : metode observasi, metode wawancara dan metode dokumentasi. Pengambilan data pada responden masyarakat dalam konflik politik dalam proses pemilihan Kepala Desa di Desa tarempa barat sebagai informen penelitian. Analisa data menggunakan analisa data kualitatif.

Studi ini memberi focus perhatian pada Konflik Politik Dalam Proses Pemilihan Kepala Desa oleh sebab itu studi ini tidak menganalisis bagaimana proses terjadinya konflik komunal pasca pemilihan kepala desa.

Pembeda dari tinjauan karya sebelumnya dengan Penelitian ini yaitu tidak membahas tentang konflik komunal yang terjadi pasca pemilihan kepala desa. Dimana, berbicara mengenai konflik komunal sangatlah penting dibahas karena sangat bermanfaat dan sangat membantu dalam literatur kajian ilmu politik.

\section{METODE PENELITIAN}

Istilah metode penelitian terdiri atas dua kata, metode dan penelitian.Metode berasak dari bahasa Yunani yaitu Methodos yang berarti cara atau jalan untuk mencapai sasaran atau tujuan dalam pemecahan suatu malasah. Dalam artian suatu usaha untuk mencapai sesuatu dengan metpde tertentu, dengan cara hati-hati, sistematik dan sempurna terhadap permasalahan yang dihadapi. Jadi metode penelitian adalah suatu cara dalam hal pemecahan terhadap suatu masalah yang sedang dihadapi.

\section{HASIL DAN PEMBAHASAN}

Masyarakat Desa Jermun yang menyebut dirinya Nahdlatul Ulama yang kultural, dalam praktek keagamaan masyarakat menanamkan ahlussuannah wal jamaah yang di pegang teguh oleh masyarakat yang mencerminkan dirinya Nahdlatul Ulama. Kemudian dalam peraktek keagaman bisa dilihat dari bagaiamana masyarkat melakasanakan sholat berjamah yang bisa kita liahat ciri khas dari Nahdlatul ualama jika megerjakan shoalat jumat degan azan dua kali. Bisa juga di lihat dari cara berpakaian orang Nahdaltul Ulama selalu memakai sarung ketika melaksanakan sholat.

Dilihat dari secara peraktek keagaman Nahdlatul Ulama sering menunjukan kekeluargaan yang kental dengan kebersaman dengan masayarakat yang menjalin 
sialahturahmi yang baik antar setiap warganya, Nahdlatul Ulama yang menjadi suatu pemersatu dan kekompakan masyarat yang kental dengan tradisi dan idiologi ahlussuannah wal jamaah. Keduddukan Nahdlatul Ulama yang dilihat secara kasat mata yang menjadikan Nahdalatul Ulama sebagai suatau ajaran yang di pegang taguh sampai sekarang ini, namun tetap eksis walaupun pada saat ini kemajuan zaman terus berkembang. (Dwi Mahendra, 2020)

Dalam mengimplementasikan Nahdlatul Ulama di Desa Jermun menjadi suatu ajaran yang di yakini membawa kebaikan atau kemaslahatan bersama bagi masyarakat di Desa Jermun, keadaan ini membuat kedudukan starategis Nahdatul Ulama menjadi kuat setelah kadernya ikut kontestasi politik dalam pemeilihan kepala desa yang tepatnya di Desa Jermun Kecamatan Pampangan Ogan Komering Ilir. Yang menariknya ketika dalam kontestasi politik pada tahun 2016 kader Nahdlatul Ulama bersama- sama mencalonkan diri sebagai calon kepala desa dan mengikuti kontestasi dalam pemilihan kepala desa, tiga pasang calon yang berasal dari keorganisasian yang sama yaitu Nahdlatul Ulama yang kultural.Kedududukan Nahdlatul Ulama Desa Jermun yang kultural bukan struktural yang menjadi peran penting dalam pemilihan kepala desa masyarakat Desa Jermun yang mengklim dirinya Nahlatul Ulama, masyarakat Desa Jermun sebagai masyarakat yang mayaoritas memeliuk agama islam yang secara ajaraan dan praktek keagamaannya yang seperti mengadakan tahlilan, yasinan yang sering dialakaukan masyarakat dengan secara bergilir di rumah warga yang tertimpah musibah.

Konflik yang terjadi di Desa Jermun karena adanya persaingan politik pemilihan kepala desa pada tahun 2016, yang terjadi antar kader Nahdlatul Ulama yang membuat persaingan yang sangat sengit membuat emosional dalam pilkada semangkin meruncing antar pendukung dari tiga pasang calon yang sedang bersaing merebutkan kekuasaan untuk menjadi kepala desa. Akar dari konflik yang terjadi menyebabkan jarak anatar masyarkat yang mendukung pasangan masing-masing calon membuat mereka saling menjaga jarak antar sesama pendukung tiga pasangan calon yang bersaing dalam pemilihan kepala desa sosial kemasyarakatan dalam sehari-hari masayarakat yang berkonflik menjadi terasa cengang, akibat konflik pada waktu sebelum pemilihan kepala desa yang masayrakat terbiasa konpak dalam segala bentuk kegitan masayarakat seakan menjaga jarak antar sesamanya. Danpak yang di timbulkan bukan hanya dalam interaksi masyarakat sehari-hari akan tetapi dalam hubungan emosional kemasayarakat juga berdanpak yang biasanya masayrakat Desa Jermun yang hubungan emosinal yang baik akibat adanya konflik menjadi tidak baik dalam berkomunikasi dengan antar masyarakat sekitar menjadi tidak baik. Sealin berkomunikasi yang tidak baik antar masyarakat dan kepada tetangga sekeliling meraka tidak adanya rasa saling percara antar masayarakat hal ini membuat semangkin terlihat danpak yang di timbulkan dari konflik yang terjadi di tengah-tengah masyarakat Desa Jermun, bukan hanya itu saja danpak yang di timbulkan ketika masyarakat berkonflik di dalam bidang ekonomi biasanya masyarakat malaksanakan pebelian bahan makanan di warung tetangganya dengan tidak bayar atau 
hutang tidak jadi masalah ketika konflik yang terjadi membuat keadaan berubah sekarang tidak bisa lagi hutang karena si pembeli dan penjual beda pilihan karena itulah untuk hutang sudah tidak boleh lagi. Dampak yang di timbulkan dari konflik yang terjadi pra pemilihan kepala desa membuat keadaan yang bisanya damai dan tentam berubah menjadi tidaak seperti biasanya hal ini seakan berubah secara drastis. Melihat keadaan yang seperti ini membuat masyarakat menjadi semangkin paham bagaimana dampak dari sebuah konflik yang di timbulkan hal ini cukup mendasar ketika perbedaan pilihan dan mendukung pasang calon yang berbeda menimbulkan konflik yang berkepanjangan. (Siamboh, 2020)

Akar konflik yang terjadi pada tahun 2016 terus meruncing dan berimbas dalam hubungan antar masyarakat sampai tahun 2017 (+- 1 tahun)konflik yang terjadi Dalam kontestasi politik yang terjadi di Desa Jermun terlihat pada sisi persaingan ketat dalam merebut kekuasaan. yang menjadi menarik adalah karena anatar pendung saling menegeluarkan statment bahwa calon yang didukung akan memenangkan pemilihan kepala desa di Desa Jermun. Sikap dalam mendukung pasangan calon yang membuat antar pendukung sering terjadi perselisihan seperti pendukung tiga pasang calon yang beradu argumen yang saling menonjolkan pasangan masing-masing antar pendukung, yang membuat masyarakat seakan sudah mengetahui akan hasil yang di dapat dalam pemilihan langsung pada priode 2016 persaingan ini tentu tidak lepasnya dari masingmasing calon ingin meraup suara terbanyak dari pemilihan kepala desa walupaun kampanye yang dilakukan dari tiga pasang calon tidak terlihat seperti pemilihan yang lebih besar dari sekala Bupati atau DPRD tapi hal ini di lakuakan berkanpanye melalui datang langsung kerumah warga masyarakat yang ada di Desa Jermun, ketika berkanpanye tiga calon kepala desa ini melakukan interaksi secara langsung dengan warga yang ditemuinya disana calon tersebut memiohon batau atau dukungan kepada warga agar memilih calon ketika pemilihan kepala desa. Tak hayal semua yang di lakukan oleh tiga colon menjadi perhatian warga yang berbeda dukungan sontak menjadikan hal yang jarang terjadi menjadi lumrah di lihat pada pemilihan kepala desa 2016 di Desa Jermun. Dalam menarik dukunganya setiap calon mempunyai cara masing-masing yang pada dasarnya untuk mencapai tujuan yaitu kekuasaan yang di ketahui tiga calon adalah semua berasal dari kader Nahdlatul Ulama yang kultural akan tetapi dalam persaingan ini demi mendapatkan dukungan tiga calon sering kali menjelekan satu dengan yang lainya. Seperti mencari kesalahan calon lainya demi menjatuhkan agar masyarakat tidak memilih calon tersebut demi kepentingan pribadinya yang menjadikan semuanya dia paling layak untuk dipilh masayrakat dalam pemilihan kepala desa.

Dalam pemilihan kepala desa yang terjadi pada tahun 2016 banyak menimbulkan konflik yang terjadi pada masyarakat antar pendukung tiga pasang calon yang ikut dalam kontestasi politik yang sama-sama ingin menang dalam pemilihan secara langsung. Konflik yang biasanya terjadi menimbulkan gesekaan antar pendukung yang mengakibatkan kesengangan sosial pada masyarakat yang berada di Desa Jermun, pada 
dasarnya akar dari konflik yang terjadi karena pendukung yang ingin memenagkan calon yang didukungnya dalam kontestasi pilkades di Desa Jermun. (Irzan, 2020)

Konflik yang terjadi ketika pemilihan kepala desa pada waktu itu menyebabkan adanya geskan antar pendukung pasca pemilihan kepala desa pada masayarkat Jermun, sebelum pemilihan kepala desa terjadi pada waktu itu masayarakat masih melakukan aktivitas seperti biasa ketika pemilihan kepala desa dimulai berubah drastis karena setiap mayarakat yang mendukung calon masing-masing berkumpul dengan sesama pendukung jadi jarak antar pendung terlihat semangkin jelas ini penyebab terjadinya konflik semangkin panas ketika tiga pasang calon di tetapkan untuk maju dalam pemilihan kepala desa.

Adapun bentuk-bentuk konflik yang terjadi di Desa Jermun pada waktu itu.Terjadinya argumen antar pendukung, saling merendahkan antar pendukung lain dan terjadinya gesekan-gesekan membuat semangkin panas konflik antar pedukung pasca pemilihan kepala desa. Pemilihan kepala desa yang terjadi di Desa Jermun adalah acara lima tahun sekali yang membuat mayarakat antusias dalam menyabut pemilihan kepala desa membuat seakan pesta tahunan yang di nanti untuk memberikan suaranya untuk mememili pemimpin yang membuat perubahan pada mayakat. Yang menginginkan kemajuan untuk Desa Jermun, setiap masyarakat pasti mencari pemimpin yang bisa membuat masyarakatnya makmur dan berbuat banyak untuk kemaslahatan bersama untuk seluruh rakyatnya.

Konflik yang terjadi di Desa Jermun membuat keadaan masyarakat semula nampak sperti biasa menjadi tidak biasa di karenakan perbedaan pendukung membuat masyarakat semangkin terlihat berkelompok-kelompok, dan tidak berbaur dengan masyarakat berbeda pilihan keadan ini membuat seperti jarak yang tidak mungkin disatukan akan tetapi keadaan pendukung tidak serta merta terlihat antar tiga pasang calon yang bersaing sikap tiga pasang calon ternyata lebih dewasa mereka nampak biasa tidak ada perubahan sama sekali. Menjelang pemilihan kepala desa yang dilaksanakan mereka seperti tidak sedang bersaing untuk memperbutkan kekuasaan tetap tegur sapa ketika bertemu di lingkungan masyarakat, dengan ini ternyata pasangan calon bersepakat ketika diantara mereka memenagkan pemilihan kepala desa mereka harus menerima dengan lapang dada yang jelas siapun menjadi kepala desa harus siap menjalankan tugas dan amanya sebagai pemimpin yang amanah dan demi kepentingan bersama dan kemaslahatan seluruh masyarakat Desa Jermun. Pada dasarnya pemilihan kepala desa ini membuat masyarakat menjadi agar lebih dewasa dalam memberikan suaranya dalam pemilihan kepala desa agsar mendapatkan pemimpin yang bisa membawa perubahan bagi masyarakat, konflik yang terjadu pasca pemilihan kepala desa sebagai bumbu dalam persaingan politik sesama kader Nahdlatul Ulama dalam memperbutkan kekuasaan yang selama ini mereka nantikan dan harapapan setiap pasang calon.

Ternyata setiap pasangan calon punya cara masing-masing dalam mendekatkan diri terhadap masyarakat yang ada di Desa Jermun dengan secara kekeluargaan yang di 
harapkan ampu dalam menggaet masyarakat untuk memimlih masing-masing mereka, ada juga dengan cara mendekatkan diri dengan remaja-remaja melalui kegiatan olaraga yang menutnya ampuh untuk mendapatkan suara terbanyak ketika pemilihan kepala desa dan ada juga pasang calon mendekatkan diri kemasyarakat dengan cara mendatangi rumah masyarakat untuk memintak bantuan untuk memilih dia ketika pemilihan berlangsung agar calon tersebut bisa memenagkan pemilihan kepala desa yang di adakan di Desa Jermun.

Pemilihan yang membuat masyarakat menjadi penentu kemenagan tiga pasang calon membuat tiga pasang calon bersaing untuk menarik masayarakat untuk memilih dalam memberikan suara terbanyaqk agar bisa menjadi kepala Desa Jermun ini yang memicu semangat semua tim sukses tiga psang calon berkerja keras dalam mempengaruhi masyarakat agar suka dengan pasang yang di dukung oleh tim suksesnya, dan mampu memenangkan dalam kontestasi politik terjadi di Desa Jermun.

Keadaan ini yang membuat menarik pemilihan kepala Desa Jermun karena tiga calon saling di letarbelakangi organisasi yang sama Nahdlatul Ulama yang kultural pemilihan terdahulu belum pernah terjadi dalam pemilihan kepala desa di Desa Jermun terjadi pesaingan antar kader Nahdlatul Ulama yang sama merebutkan kekuasaan dalam kontestasi politik. Ketika dalam kontestasi yang terjadi membuat ikut berpatisipasi dalam pemilihan tersebut membuat semangkin seru antar masyarakat yang mendukung tiga pasang calon ikut berpatisipasi dalam pemilihan tersebut membuat semangkin seru antar masyarakat yang mendukung tiga pasang calon yang ingin menjadi orang no satu di Desa Jermun. (Abusroni, 2020)

Pemilihan ini adalah ajang kontestasi bagi kader Nahdlatul Ulama dalam menunjukan taringnya untuk mencapai suatu kekuasan melalui pemilihan kepala desa yang di laksanakan di Desa Jermun Kecamatan Pampangan Ogan Komering Ilir pada tahun 2016. Pada intinya pada tahun 2016 adalah ajang bagi kader Nahdlatul Ulama dalam pemilihan yang membuat masa keemasan Nahdlatul ulama semangkin menjadi suatu organisasi yang cukup menunjukan eksistensinya lebih meninkat setiap tahunya, di karenakan menjadi mayoritas masyarakat memegang teguh idiologi ahlussuannah wal jamaah yang berdasarkan dari turun temurun dari nenek moyang dan tradisi yang sangat kental dengan keagaamaanya. Yang sudah melekat dengan diri masyarakat Desa Jermun secara kultur budaya yang di wariskan dari turun temurun dari orang tua terdahulu keadaan ini membuat masyarakat menjadi semangking terasa kekeluargaanya dalam mendukung kelurga atau kerabatnya dalam memncalonkan diri sebagi kepala Desa Jermun yang ikut dalam kontestasi pemilihan kepala desa.

Terjadinya konflik komunal di Desa Jermun karena andanya persaingan politik yang maengakibatkan masyarakat berkonflik yang mengakibatkan semua ikut dalam konflik terutaama antar pendukung yang mengiginkan calonnya menang dalam pemilihan kepala desa di Desa Jermun pada tahun 2016, hal ini adalah salah satu pemicu masyarakat berkonflik igin menunjuukan eksistensi sebagai pendukung dari golongan tertentu danpak 
myang terjadi bukan hanya menyebabkan msayarakat tidak saling tegur sapa dengan tetangga akan tetapi terjadinya acuh tak acuh dengan kerabat dan keluarga yang beda pilihan dengan calon yang maju dalam pemilihan kepala desa.

Konflik adalah sebagai alat untuk mencapai kekuasaan yang di inginkan antara pasang calon yang bersaing untuk mancapai tujuan dalam pemilihan kepala desa salah satu untuk memeca pendukung agar berbalik mendukung pasangan calon dan starategi politik yang dimainkan demi meraup suara terbanyak dalam pemilihan kepala Desa Jermun Kecamatan Pampangan Ogan Komering Ilir pada tahun 2016. Mencari suara dalam pemilihan kepala desa bukan semudah membalikan tangan karena masyarakat memiliki siakap dan kepribadian yang berbeda-beda yang membuat calon-calon yang bersaing harus memutar otak dan menarik masyarakat simpatik mendukung mereka agar memenangkan kontestasi politik yang sedang terjadi di Desa Jermun.

Dalam persaingan politik antar tiga pasang calon yang terus meruncing membuat keadaan semangkin tidak stabilnya kondisi Desa Jermun membuat semua masyarakat terlibat konflik antar warganya imbas dari pemilihan kepala desa pada tahun 2016, dalam terjadinya konflik yang terjadi sikap kedewasaan masyarakat sedang di uji untuk menjadi masyarakat yang pintar dalam memeilih calon agar mampu menjadi pemimpin yang siap mengemban amana dan berbuat banyak bagi masyarakat Desa Jermun Kecamatan Pampangan Ogan Komering Ilir.

Konflik antar pendukung membuat semua element masyarakat menjadi terlibat dalam konflik yang berujung dengan saling menegejek antar pasang calon yang ikut dalam pemilihan kepala desa, akan tetapi tidak sampai dengan perkelahian yang mengakibatkan jatuhnya korban nampaknya semua masyarakat sedikit lebih paham dengan artinya bersaing dalam berpolitik karena dalam suatu konflik tidak harus dengan peneylesaiaan dengan kekerasan yang erujung maut. Walaupun dalam beda pendukung masyarakat masih menjaga tata cara bersaing dengan mengunakan akal sehat yang tidak berujung dengan pertikaian apalagi sampai memakan korban dan itu sangat merugikan bagi masyarakat itu sendiri. (Hambali, 2020)

Persaingan politik guna mencapai kekuasaan sebagiam dari salah satu tujuan dari politik itu sendiri, bukan karna itu saja politik adalah sebagai untuk menjalankan visi misi yang ingin dicapai dari pasang calon demi mewujudkan kepentingan bersama. Mejalankan amanah bukan hal yang mudah ketika menjadi ketua dari sebuah desa atau kepala desa yang di emaban agar mampu mendengar suara rakyat yang mendukung dan tidak mementingkan golongan manapun, hakikatnya menjadi seorang pemeimpin agar mampu menjalakan amanah yang telah di cita-citakan oleh masyarakat dilikungan Desa Jermun. Pemilihan kepala desa tak lepas dari keinginan masyarakat untuk mencari pemimpin yan adi dan bijaksana butuh prmikiran yang satu langkah lebih maju di bandingkan masyarakat yang memeilihnya agam mampu menjadikan masyarakat hidup aman dan tentram dalam kehidupan sehari-hari, hal ini lah yang memicu tiga pasang calon merasa pantas dan ingin bersaing dalam pemilihan kepala desa ayng berlangsung pada 
tahun 2016 dan taklepas dari itu ini lah menyebabkan konflik yang terjadi dan persaingan menjadikan semangkin panas karena sama-sama ingin menjadi orang no 1 di Desa Jermun Kecamatan Pampangan.

Pada hakikatnya konflik yang terjadi antar pendukung menjadikan pemilihan kepala desa semangkin menarik mebuat semua nampak nyata antar pendukung siapasiapa saja yang mendukung dan siapa-siapa saja yang tidak mendukung, karena ini menyebabkan ada kelompok sendiri-sendiri yang mendukung calon pasca pemilihan kepala desa hal ini tidak serta merta menbuat masyarakat yang dulunya bisa satu kesataun yang kompak ketika dalam keadaan sosial antar masyarakat ketika pemilihan kepala desa terlihat kelompok-kelompok pendukung yang berbeda pilihan satu sama lainya.

Keadaan ini berlangsung cukup lama setelah di tetapkanya siapa saja yang mencalonkan diri di sebagai calon kepala desa sudah nampak konflik antar pendukung mulai terasa menjadikan persaingan nampak menarik karena tiga pasang calon saling menginginkan kedudukan kepala desa, yang menjadikan persaingan tiga pasang calon sangat sengit dalam pemilihan kepala desa di Desa Jermun Kecamatan Pampangan Ogan Komering Ilir.

Pemilihan ini tidak serta merta membuat masyararakat Desa Jermun menjadi masyarakat yang anti dengan demokrasi akan tetapi menyambut dengan antusias dalam menyalurkan hak suaranya dalam pemilihan kepala desa, secara demokrasi yang memimilih pasangan tiga calon dengan datang ke tps setempat untuk membrikan hak suaranya. Yang menjadikan keadaan semangkin tanpak tidak ada konflik di belakang itu tatapi kenyataan yang sebenarnya masyarakat sebelum pemilihan berlangsung antar masayarakat,tetangga,kereabat dan saudara terjadi konflik karena beda pilihan dan pendukung satu sama lainya. Hal ini menjadi tanpak menjadi pemandangan tersendiri ketika pemilihan kepala desa pada tahun 2016 yang terjadi di Desa Jermun.

Pada dasarnya pemilihan kepala desa adalah persaingan antar tiga calon yang berkompetisi dalam merebutkan keskuasan yang pada dasarnya untuk kemajuan suatu daerah atau desa yang melibatkan seluruh element masyarakat untuk menyuarahkan suaranya dalam mencari sesosok pemimpin yang adil dan bijaksana, terlepas dari itu semua hal ini menimbulkan konflik yang berkepanjangan kurang lebih satu tahun dari tahun 2016-2017 setelah pemilihan kepala desa konflik itu masih saja ada tak hayal ini membuat pemimpin yang baru atau kepala desa merasa tidak nyaman dengan keadaan yang ada di masyarakatnya dengan adanya penengah dari sebuah permassalahan yang terjadi kepala desa yang baru mengadakan pertemuan kepada seluruh masayarat untuk membahas bagaimana suatu konflik ini harus di hentikan atau di damaikan secara musyawarah kepada seluruh element masayarat yang terlibat konflik pada pra pemilihan kepala desa. Akhirnya masyarakat dengan lapang dada mnerima hasil dari musyawarah untuk berdamai dan menjalakan kehidupan sehari-hari tanpa adanya perasanka buruk lagi antar sesama warga,keluarga,kerabat dan kepada kepala desa yang baru. 


\section{Faktor - Faktor Terjadinya Konflik Komunal Di Desa Jermun}

Didalam masyarakat berkonflik tentu saja ada peneyabab dari timbulnya konflik pasca pemilihan kepala desa yang dilaksanakan di Desa Jermu pada tahun 2016. Yang membuat masyarakat mengerti dengan keadaan yang terjadi pasca pemilihan kepala desa adapun faktor terjadinya konflik sebagai berikut:

$>$ Terjadinya perbedaan pendapat tentang pasaangan calon yang bersaing dalam pemilihan kepala desa.

$>$ Bersih tengangnya anatar pedukung pasangan calon yang ikut pemilihan kepala desa.

$>$ Sikap pendukung yang ingin calon yang di dukung manang dalam pemilihan kepala desa pada tahun 2016.

$>$ Berbedanya pilihan masyarkat dalam menentukan kepala desa.

$>$ Masyarakat yang ingin melihat calon yang di dukung agar menang dalam pemilihan kepala desa.

Dari lima poin diatas dapat dilihat bahwa terjadinya konflik komunal dalam pemilihan kepala desa di Desa Jermun, terjadinya berbedanya pendapat antar pendukung yang satu dengan yang lain membuat semua masyarakat terlibat dalam konflik yang terjadi pada pasca pemilihan kepala desa. Hal ini membuat keadaan sosial masyarakat terasa merengan dan kekeluargan yang biasanya tercipta semangkin ada jarak yang sangat berbeda dari sebelum pemilihan kepala desa akan tetapi ketika hal ini menjadi pemandangan yang tidak seperti biasa, karena yang biasanya masyarakat sosial kemasyarkatanya baik-baik saja menjadi terpecah belah dan hanya kelompok-kelompok yang beriteraksi sesama mereka dan pedukung yang sama.

Dalam kontestasi politik yang terjadi di Desa Jermun pasti banyak persaingan yang membuat tenaga tiga calon terkuras habis dalam menghadapi segala yang terjadi di masayarakat dalam menhadapi persaingan memperbutkan kekuasaan, hal ini semua tenaga dan emosi tiga pasang calon yang terkuras habis tentu saja ini membuat perasaan merka bercampur senang,khawatir dan cemas dengan hasil apa yang di dapat dalam penghitungan suara yang bakal di hadapi tiga pasang calon ke khawatiran ini tentu saja tidak bisa di pungkiri karena persaingan sangat ketat. Menjadikan semuanya calon nampak gusar karena hal ini perasaan yang wajar bagi calon yang berkontestasi dalam pemilihan kepala desa pada dasarnya menjadikan semua menjadi ajang pembuktian siapa yang pantas menjadi orang yang mampu membawa Desa Jermun lebih maju lagi dari sebelumnya yang diinginkan oleh semua masayarakat yang bertempat tingal di Desa Jermun.

Persaingan yang terjadi dalam pemilihan bukan hanya janji manis yang di ucapakan oleh calon-calon akan maju tetapi masyarakat melihat bagimana kedekatan emosional calon dengan warganya itu yang di nilai masyarakat salah satu kriteria, masyarakat memilih baik dalam sosialisasi kemasayarkatan yang di lakukan sebelum pemilihan kepala desa apakah layak menjadi seorang pemimpin yang mampu membawa masyarakat 
lebih maju lagi dari sebelum-sebelumnya, sikap semacam ini yang di tunjukan masyarakat dalam memlih calon dalam pemilihan kepal desa. Ketika masyarakat sudah senang dengan calon yang mepunya hubungan dengan masyarakat baik sosial kemasyarakatan yang dijaga kemungkinan besar calon tersebut memenagkan kontestasi politik di Desa Jermun, pada dasarnya semua masyarakat pasti menginginkan sesosok pemimpin yang kemampuanya di atas rata-rata yang akan membawa kemajuan untuk desa yang bakal di pimpin oleh kepala desa yang memenangkan pemilihan yang melalui kontestasi politik yang diselengarakan pada tahun 2016. (Fausi, 2020)

Dalam perjalanan kontestasi politik di Desa Jermun tak lepas dari peran kader Nahdlatul Ulama bersaing meperbutkan kekuasan meneurut saya taklepas dari konflik yang terjadi antar warga dan masyarakat di mana hasil pembahasan saya meneliti dan hasil wawancara saya dengan tiga calon yang bersaing,tokoh agama,tokoh masayrakat dan masyarakat Desa Jermun bagimana kedudukan dan peran strategi Nahdlatul Ulama di Desa Jermun dalam pemilihan kepala desa, konflik komunal Nahdlatul Ulama kultural dan kontestasi pilkades di Desa Jermun, faktor-faktor terjadinya konflik komunal di Desa Jermun, perasangaka tiga calon dalam pemilihan kepala desa, dan sikap pemilih masyarakat Desa Jermun dalam pemilihan kepala desa pada tahun 2016.

\section{KESIMPULAN}

Konflik dalam pemilihan kepala desa antara warga Nahdlatul Ulama yang kultural sebagaimana yang di ketahui oleh peneliti bagaimana prektek dalam kehidupan seharihari seperti melakukan kegitan khatam Al- Quran, ziarah kubur, tahlilan bersama, tawasul, istigasah, dan zikir bersama. Disinilah letak dari Nahdaltul Ulama yang di sebut kultural oleh masayarat Desa Jermun.

Dalam keadan masayarakat yang mayoiritas Nahdaltul Ulama di Desa Jermun mebuat keadan keagaman yang kental denga tradisi dan budaya, hal sama sekali tidak membuat konflik komunal menjadi reda karena dalam kontestasi politik yang berlangsung di Desa Jermun para calon di latarbelakangi oleh organisasi keagamaan yang sama yaitu nahdaltul ulama yang kultural.

Dari hasil data yang di dapat melaui wawancara madiri di lakukan penulis di tarik kesimpulan bahwa konflik komunal yang terjadi pada waktu pemilihan kepala desa pada tahun 2016, karena adanya perbedaan pedukung antar tiga pasang calon hal ini yang membuat terjadinya konflik. Hal ini tentusaja di dasari denegan persainagan antara kader Nahdaltul Ulama yang maju dalam pemilihan kepala desa pada tahun 2016.

Pada intinya konflik yang terjadi di Desa Jermun cukup berlangsung lama kurang lebih satu tahun namun peneyelasain yang dilakukan oleh kades yang terpilih, melakukan kumpulan seacara kekeluargaan dengan masyarakat Desa Jermun dan ahirnya masyarakat menerima keputasan bahwa konflik harus selesaikan secara kekeluargaan. 
Setidaknya masyarakat Desa Jermun ketika peneyelesai konflik komunal dalam pemilihan kepala desa yang terjadi melalui kekeluargaan bisa menerima kades baru yang menang untuk periode 2016-2021. 


\section{DAFTAR PUSTAKA}

Abdurrahman, 2009, Fenomena Kiai dalam dinamika Politik NU. (Karsa, Volume 15 Nomor1

Clifford Gerrtz, “di Desa Jepang ”, G. William Skinner (ed), Local Ethnic, And National Loyalities in Vilage Indonesia.

Efendy, Bahtiar,1998, Islam dan Negara: Transformasi Pemikiran dan Praktik Politik Islam di Indonesia. Jakarta: Paramadina.

Maulana Ahmad Hasan, Lutfhi Hamidi dan Siti Al Mukaromah, "NU \& Peta Politik Banyumas: Potensi, Peluang, Tandangan. (Banyumas, suaramerdeka.com. November. 2016)

Muhammad Shadiq, 2004, Dinamika Kepemimpinan NU, Surabaya: Lajnah Ta'lif wa Nasyr

Peter Carey, Babad DipanegaraAkun Wabah Perang Jawa:, 1825 -1930", (Monograph of the Malaysian Branch Royal Asiatic Society: Kualalumpur, 1981).

Riswandha dalam Lexy Moleong, 2000, Metode Penelitian Kualitatif, Bandung: Rosdakarya,

Ritzer, George., Goodman, Douglas J, 2004, Teori Sosiologi Modern, Edisi Keenam, Jakarta: Kencana

Robert K. Yin, 2006, Studi Kasus Desain dan Metode, Jakarta: PT Raja Grafiondo Persada 